\title{
Front Matter: Volume 10496
}

, "Front Matter: Volume 10496," Proc. SPIE 10496, Optical Elastography and Tissue Biomechanics V, 1049601 (16 March 2018); doi: 10.1117/12.2323044

SPIE. Event: SPIE BiOS, 2018, San Francisco, California, United States 


\title{
Optical Elastography \\ and Tissue Biomechanics $V$
}

\author{
Kirill V. Larin \\ David D. Sampson \\ Editors
}

27-28 January 2018

San Francisco, California, United States

Sponsored by

SPIE

Cosponsored by

Thorlabs (United States)

Published by

SPIE 
The papers in this volume were part of the technical conference cited on the cover and title page. Papers were selected and subject to review by the editors and conference program committee. Some conference presentations may not be available for publication. Additional papers and presentation recordings may be available online in the SPIE Digital Library at SPIEDigitallibrary.org.

The papers reflect the work and thoughts of the authors and are published herein as submitted. The publisher is not responsible for the validity of the information or for any outcomes resulting from reliance thereon.

Please use the following format to cite material from these proceedings:

Author(s), "Title of Paper," in Optical Elastography and Tissue Biomechanics V, edited by Kirill V. Larin, David D. Sampson, Proceedings of SPIE Vol. 10496 (SPIE, Bellingham, WA, 2018) Seven-digit Article CID Number.

ISSN: 1605-7422

ISSN: 2410-9045 (electronic)

ISBN: 9781510614772

ISBN: 9781510614789 (electronic)

Published by

SPIE

P.O. Box 10, Bellingham, Washington 98227-0010 USA

Telephone +1 3606763290 (Pacific Time) · Fax +1 3606471445

SPIE.org

Copyright (C) 2018, Society of Photo-Optical Instrumentation Engineers.

Copying of material in this book for internal or personal use, or for the internal or personal use of specific clients, beyond the fair use provisions granted by the U.S. Copyright Law is authorized by SPIE subject to payment of copying fees. The Transactional Reporting Service base fee for this volume is $\$ 18.00$ per article (or portion thereof), which should be paid directly to the Copyright Clearance Center (CCC), 222 Rosewood Drive, Danvers, MA 01923. Payment may also be made electronically through CCC Online at copyright.com. Other copying for republication, resale, advertising or promotion, or any form of systematic or multiple reproduction of any material in this book is prohibited except with permission in writing from the publisher. The CCC fee code is 0277$786 \mathrm{X} / 18 / \$ 18.00$.

Printed in the United States of America.

Publication of record for individual papers is online in the SPIE Digital Library.

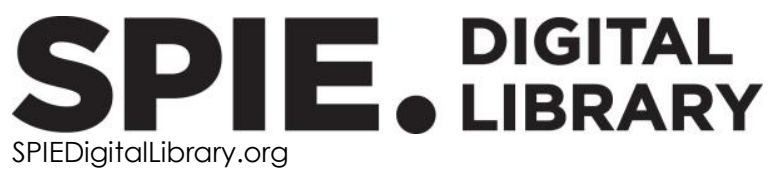

Paper Numbering: Proceedings of SPIE follow an e-First publication model. A unique citation identifier (CID) number is assigned to each article at the time of publication. Utilization of CIDs allows articles to be fully citable as soon as they are published online, and connects the same identifier to all online and print versions of the publication. SPIE uses a seven-digit CID article numbering system structured as follows:

- The first five digits correspond to the SPIE volume number.

- The last two digits indicate publication order within the volume using a Base 36 numbering system employing both numerals and letters. These two-number sets start with 00, 01, 02, 03, 04, 05, 06, 07, 08, 09, OA, OB ... 0Z, followed by 10-1Z, 20-2Z, etc. The CID Number appears on each page of the manuscript. 


\title{
Contents
}

\author{
$\checkmark$ Authors \\ vii Conference Committee
}

\section{NOVEL METHODS}

1049606 High-resolution optical polarimetric elastography for measuring the mechanical properties of tissue [10496-5]

\section{OPTICAL COHERENCE ELASTOGRAPHY II}

10496 OC Optical coherence elastography assesses tissue modifications in laser reshaping of cornea and cartilages [10496-11]

$104960 \mathrm{G}$ Comparison between thermoelastic and ablative induced elastic waves in soft media using ultra-fast line-field low coherent holography [10496-15]

$10496 \mathrm{OH}$ Structural characterization on in vitro porcine skin treated by ablative fractional laser using optical coherence tomography [10496-16]

10496 Ol High resolution SAW elastography for ex-vivo porcine skin specimen [10496-17]

\section{COMPUTATION AND MODELING}

10496 OP Viscoelastic characterization of dispersive media by inversion of a general wave propagation model in optical coherence elastography [10496-24]

\section{ELASTOGRAPHY METHODS AND APPLICATIONS}

$104960 Z$ Cartilage microindentation using cylindrical and spherical optical fiber indenters with integrated Bragg gratings as force sensors [10496-34]

1049611 Measuring in-vivo and in-situ ex-vivo the 3D deformation of the lamina cribrosa microstructure under elevated intraocular pressure [10496-36]

TISSUE MECHANICAL PROPERTIES

1049617 Thermo-mechanical mechanism of laser-assisted alteration and stabilization of micro pore structure in eye-sclera [10496-42] 
10496 IE The potential of high intensity focused ultrasound (HIFU) combines phase-sensitive optical coherence tomography (PhS-OCT) for diseases diagnosis, treatment, and monitoring [10496-50]

1049611 Brillouin light scattering spectroscopy for tissue engineering application [10496-54] 


\section{Authors}

Numbers in the index correspond to the last two digits of the seven-digit citation identifier (CID) article numbering system used in Proceedings of SPIE. The first five digits reflect the volume number. Base 36 numbering is employed for the last two digits and indicates the order of articles within the volume. Numbers start with 00, 01, 02, 03, 04, 05, 06, 07, 08, 09, 0A, 0B...0Z, followed by 10-1Z, 20-2Z, etc.

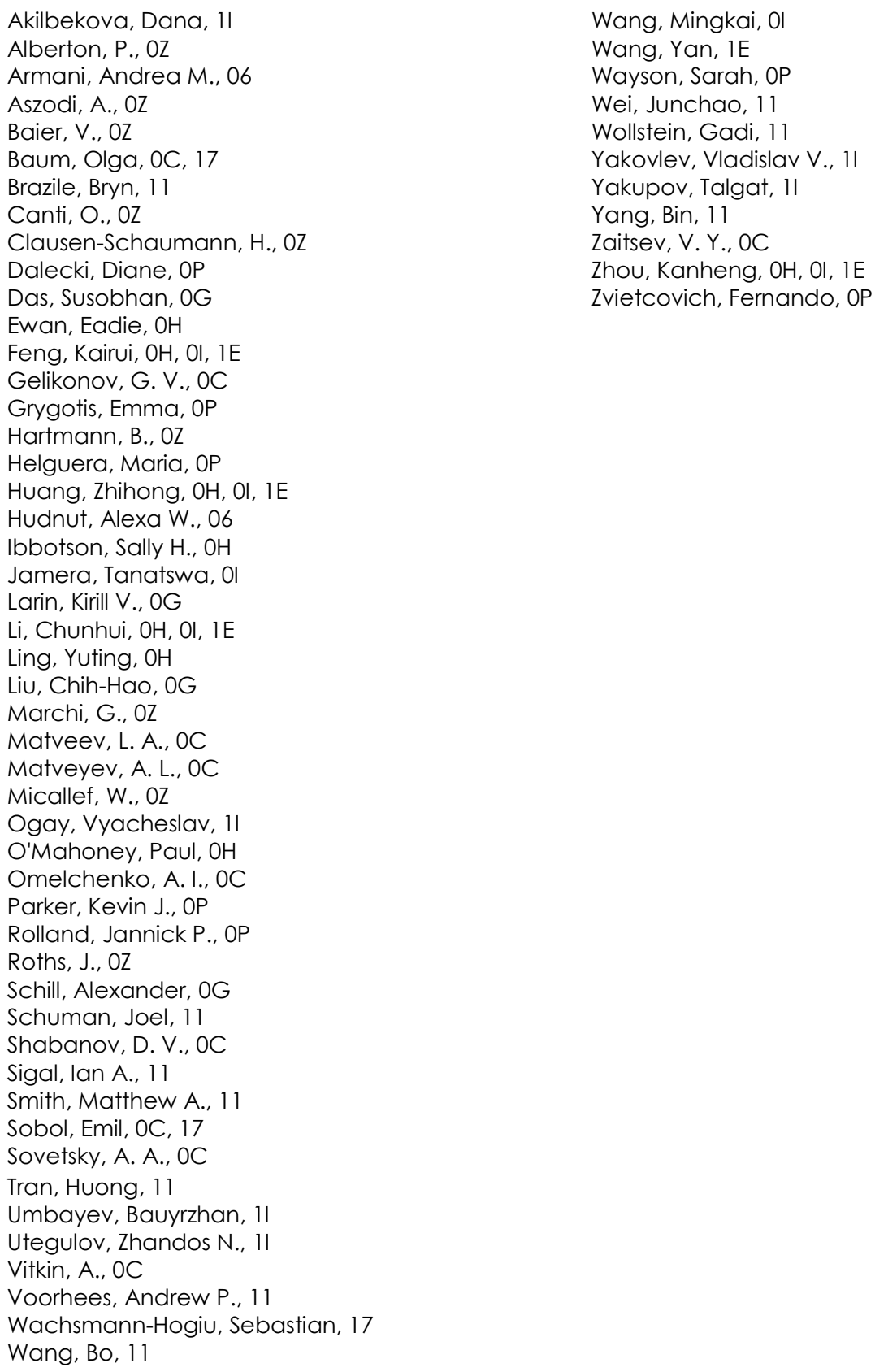


Proc. of SPIE Vol. 10496 1049601-6

Downloaded From: https://www.spiedigitallibrary.org/conference-proceedings-of-spie on 26 Apr 2023 Terms of Use: https://www.spiedigitallibrary.org/terms-of-use 


\title{
Conference Committee
}

\author{
Symposium Chairs
}

James G. Fujimoto, Massachusetts Institute of Technology

(United States)

R. Rox Anderson, Wellman Center for Photomedicine, Massachusetts

General Hospital (United States) and Harvard Medical School

(United States)

Program Track Chair

Steven L. Jacques, Tufts University (United States)

Conference Chairs

Kirill V. Larin, University of Houston (United States)

David D. Sampson, The University of Western Australia (Australia)

\section{Conference Program Committee}

Jeffrey C. Bamber, Institute of Cancer Research (United Kingdom)

Albert Claude Boccara, Institut Langevin (France)

Stephen A. Boppart, University of Illinois at Urbana-Champaign (United States)

Brett E. Bouma, Wellman Center for Photomedicine, Massachusetts General Hospital (United States)

Zhongping Chen, Beckman Laser Institute and Medical Clinic (United States)

Kishan Dholakia, University of St. Andrews (United Kingdom)

Christine P. Hendon, Columbia University (United States)

Davide Iannuzzi, Vrije University Amsterdam (Netherlands)

Brendan F. Kennedy, The University of Western Australia (Australia)

Sean J. Kirkpatrick, Michigan Technological University (United States)

Seemantini K. Nadkarni, Harvard University (United States)

Matthew O'Donnell, University of Washington (United States)

Amy L. Oldenburg, The University of North Carolina at Chapel Hill (United States)

Gabriel Popescu, University of Illinois at Urbana-Champaign (United States)

Jannick P. Rolland, University of Rochester (United States)

Giuliano Scarcelli, University of Maryland, College Park (United States)

Gijs van Soest, Erasmus MC (Netherlands) 
Peter Török, Imperial College London (United Kingdom)

Ruikang K. Wang, University of Washington (United States)

Vladislav V. Yakovlev, Texas A\&M University (United States)

Seok Hyun A. Yun, Harvard University (United States)

Vladimir Y. Zaitsev, Russian Academy of Science Nizhny Novgorod (Russian Federation)

Qifa Zhou, The University of Southern California (United States)

\section{Session Chairs}

1 Novel Methods

Stephen Allen Boppart, University of Illinois at Urbana-Champaign (United States)

Kishan Dholakia, University of St. Andrews (United Kingdom)

Jannick P. Rolland, University of Rochester (United States)

2 Optical Coherence Elastography I

Sean J. Kirkpatrick, Michigan Technological University (United States)

3 Optical Coherence Elastography II

Giuliano Scarcelli, University of Maryland, College Park (United States)

4 Cellular Biomechanics and Applications I

Albert Claude Boccara, Institut Langevin (France)

5 Computation and Modeling

Brendan F. Kennedy, The University of Western Australia (Australia)

Vladislav V. Yakovlev, Texas A\&M University (United States)

6 Brillouin Elastography

Zhongping Chen, Beckman Laser Institute and Medical Clinic (United States)

Matthew O'Donnell, University of Washington (United States)

7 Cellular Biomechanics and Applications: Joint Session with

Conferences 10496 and 10503

Kirill V. Larin, University of Houston (United States)

YongKeun Park, KAIST (Korea, Republic of)

Gabriel Popescu, University of Illinois at Urbana-Champaign (United States)

David D. Sampson, The University of Western Australia (Australia) 
8 Elastography Methods and Applications

Ruikang K. Wang, University of Washington (United States)

Shaozhen Song, University of Washington (United States)

9 Tissue Mechanical Properties

Amy L. Oldenburg, The University of North Carolina at Chapel Hill (United States)

Qifa Zhou, The University of Southern California (United States) 
Proc. of SPIE Vol. 10496 1049601-10 Downloaded From: https://www.spiedigitallibrary.org/conference-proceedings-of-spie on 26 Apr 2023
Terms of Use: https://www.spiedigitallibrary.org/terms-of-use 